\title{
MODEL PEMBELAJARAN PROBLEM BASED LEARNING (PBL) DENGAN MEDIA AUDIO VISUAL UNTUK MENINGKATKAN PRESTASI BELAJAR PKN
}

\author{
Ni Wayan Suwarni
}

\author{
SD Negeri 2 Tulikup \\ e-mail: wayansuwarni11@gmail.com
}

\begin{abstract}
Abstrak
Penelitian ini dilaksanakan di SD Negeri 2 Tulikup di kelas VI yang kemampuan siswanya untuk pelajaran PKn masih sangat rendah. Tujuan penulisan penelitian tindakan kelas ini adalah untuk meningkatkan prestasi belajar PKn siswa kelas VI SD Negeri 2 Tulikup pada semester I tahun pelajaran 2017/2018 melalui penerapan model pembelajaran Problem Based Learning dengan media audio visual. Metode pengumpulan datanya adalah tes prestasi belajar. Metode analisis datanya adalah deskriptif baik untuk data kualitatif maupun untuk data kuantitatif. Hasil yang diperoleh dari penelitian ini adalah penerapan model pembelajaran Problem Based Learning dengan media audio visual dapat meningkatkan prestasi belajar siswa. Ini terbukti dari hasil yang diperoleh pada awalnya mencapai nilai rata-rata 69,68, pada siklus I mencapai nilai rata-rata 75,31 dan pada siklus II mencapai nilai rata-rata 81,25. Presentase ketuntasan belajar siswa juga mngalami peningkatan. Pada awal pembelajaran ketuntasan belajar siswa hanya mencapai $46,87 \%$. Pada siklus I mengalami peningkatan menjadi $75,00 \%$, dan pada siklus II ketuntasan belajar siswa meningkat menjadi $96,87 \%$. Kesimpulan yang diperoleh dari penelitian ini adalah penerapan model pembelajaran Problem Based Learning dengan media audio visual dapat meningkatkan prestasi belajar PKn siswa kelas VI semester I SD Negeri 2 Tulikup tahun pelajaran 2017/2018.
\end{abstract}

Kata-kata kunci : Model Pembelajaran Problem Based Learning, Media audio visual, Prestasi belajar PKn

\begin{abstract}
This research was conducted at SD Negeri 2 Tulikup in class VI where the ability of students for Civics Education was still very low. The purpose of writing this class action research is to improve the learning achievement of Civics in class VI students of SD Negeri 2 Tulikup in the first semester of the academic year 2017/2018 through the application of the Problem Based Learning learning model with audio visual media. The data collection method is a learning achievement test. The data analysis method is descriptive both for qualitative data and for quantitative data. The results obtained from this study are the application of the Problem Based Learning learning model with audio visual media can improve student learning achievement. This is evident from the results obtained initially reaching an average value of 69.68 , in the first cycle reaching an average value of 75.31 and in the second cycle achieving an average value of 81.25. The percentage of students' mastery learning has also increased. At the beginning of learning mastery learning students only reached $46.87 \%$. In the first cycle increased to $75.00 \%$, and in the second cycle students' learning completeness increased to $96.87 \%$. The conclusion obtained from this study is the application of the Problem Based Learning learning model with audio visual media can improve the learning achievement of Civics in the sixth grade students of SD Negeri 2 Tulikup in the academic year 2017/2018.
\end{abstract}

Keywords: Problem Based Learning Learning Model, audio visual media, Civics Learning Achievement 


\section{Pendahuluan}

Pendidikan merupakan kebutuhan mutlak bagi kehidupan manusia yang harus dipenuhi. Tanpa pendidikan mustahil manusia dapat berkembang secara baik. Pendidikan dapat diartikan sebagai sebuah proses dengan metode-metode tertentu sehingga orang memperoleh pengetahuan, pemahaman, dan cara bertingkah laku yang sesuai dengan kebutuhan. Penyelenggaraan pendidikan di Indonesia menurut UU Nomor 20 Tahun 2003 pasal 1 ayat (2) disebutkan bahwa suatu Pendidikan Nasional adalah pendidikan yang berdasarkan Pancasila dan Undang-Undang Dasar 1945 yang berakar pada nilai-nilai agama, kebudayaan nasional Indonesia dan tanggap terhadap tuntutan perubahan zaman.

Pendidikan merupakan sebuah sistem. Sebagai sistem, aktivitas pendidikan terbangun dalam beberapa komponen, yaitu pendidik, peserta didik, tujuan pendidikan, alat pendidikan, dan lingkungan pendidikan. Semua komponen yang membangun sistem pendidikan, saling berhubungan, saling tergantung, dan saling menentukan satu sama lain. Setiap komponen memiliki fungsi masing-masing dalam rangka mencapai tujuan pendidikan. Aktivitas pendidikan akan terselenggara dengan baik apabila didukung oleh komponen-komponen dimaksud. Fungsi pendidikan sebenarnya adalah menyediakan fasilitas yang dapat memungkinkan tugas pendidikan dapat berjalan lancar, baik secara struktural, maupun secara institusional. Secara struktural menuntut terwujudnya struktur organisasi yang mengatur jalannya proses kependidikan. Secara institusional mengandung implikasi bahwa proses kependidikan yang terjadi dalam struktur organisasi itu dilembagakan untuk lebih menjamin proses pendidikan itu berjalan secara konsisten dan berkesinambungan mengikuti kebutuhan dan perkembangan manusia yang cenderung ke arah tingkat kemampuan yang optimal Masyarakat dalam penyelenggeraan pendidikan, kadang tidak menyadari bahwa pendidikan terbangun dalam sebuah sistem, sehingga dalam melaksanakan penilaian terhadap aktivitas dan hasil pendidikan, mereka hanya melemparkan tanggung jawab keberhasilan dan kegagalan pendidikan kepada satu kelompok, yaitu guru. Sebagian masyarakat kurang menyadari, bahwa sesungguhnya mereka adalah salah satu komponen yang turut menentukan keberhasilan atau kegagalan pendidikan. Mereka sering melempar tanggung jawab kegagalan pendidikan hanya kepada guru. Pada hal guru hanya merupakan salah satu sub komponen dari komponen dalam sistem pendidikan yang diselenggerakan. Sebagian masyarakat mengkonotasikan pendidikan dengan persekolahan, pada hal keduanya mempunyai perbedaan, walaupun tetap mempunyai hubungan. Pemahaman tentang adanya faktor-faktor determinan dalam pendidikan merupakan hal yang penting, karena kesalahpahaman tentang hal itu, dapat menjadikan kesalahan dalam memberikan penilaian, terutama pada hal-hal yang merupakan kegagalan pendidikan. Tidak jarang ditemukan penilaian yang kurang adil dari masyarakat terhadap sebuah pelanggaran pendidikan yang dilakukan oleh orang-orang yang dianggap terpelajar, dengan mengatasnamakan kegagalan pendidikan, terutama pendidikan persekolahan (formal), tentunya yang menjadi sasaran adalah para guru. Guru/pendidik di sekolah hanya merupakan bagian kecil dari sistem pendidikan, hanya sebagai bagian dari sub sistem pendidik dalam arti luas, yang meliputi pendidik di rumah tangga, pendidik di sekolah, dan pendidik dalam masyarakat (Saat, 2015).

Tujuan dari suatu proses pembelajaran adalah untuk membentuk anak didik dalam suatu perkembangan tertentu. Dalam suatu proses belajar mengajar, aspek yang sangat penting untuk mencapai tujuan tersebut adalah peran aktif atau partisipasi antara guru dan siswa. Partisipasi antara keduanya sangat berpengaruh terhadap pencapaian tujuan pembelajaran yang diinginkan. Hal ini dapat diartikan bahwa dalam suatu proses belajar mengajar harus ada keterlibatan antara guru dan siswa. Proses belajar itu sendiri merupakan hal yang sangat penting, dimana proses tersebut terjadi di dalam pemikiran siswa. Keterlibatan siswa dalam proses belajar mengajar merupakan suatu implementasi dari keaktifan siswa dalam proses tersebut tentu saja disamping menerima materi pelajaran dari guru siswa juga aktif baik dari segi fisik maupun mental.

Tugas guru tidak terbatas pada memberikan informasi kepada murid namun tugas guru lebih konprehensif dari itu. Selain mengajar dan membekali murid dengan pengetahuan, guru 
juga harus menyiapkan mereka agar mandiri dan memberdayakan bakat murid di berbagai bidang, mendisiplinkan moral mereka, membimbing hasrat dan menanamkan kebajikan dalam jiwa mereka. Guru harus menunjukkan semangat persaudaraan kepada murid serta membimbing mereka pada jalan kebenaran agar mereka tidak melakukan perbuatan yang menyimpang dari ajaran agama.

Apabila seorang guru memahami hal-hal tersebut tentu saja prestasi belajar siswa tidak akan rendah. Namun kenyataan yang ada di lapangan sangat jauh berbeda. Berdasarkan hasil observasi peneliti selaku guru di SD Negeri 2 Tulikup rata-rata prestasi belajar siswa hanya mencapai 69,68 dengan ketuntasan belajar hanya 46,87\%. Hal tersebut masih jauh di bawah KKM mata pelajaran PKn di sekolah ini yaitu 75,00.

Ada beberapa kemungkinan faktor penyebab rendahnya prestasi belajar siswa pada mata pelajaran PKn, diantaranya faktor siswa, guru, sarana prasarana, alat peraga, metode, dan proses mengajar yang kurang menarik minat siswa untuk belajar. Siswa kurang memperhatikan guru saat menerima pelajaran, kurang fokus, enggan berpikir, merasa malu dan bosan. Guru kurang persiapan dalam merencanakan pembelajaran dan kurang menguasai materi pembelajaran. Dalam proses belajar mengajar masih satu arah dan masih beranggapan guru itu segalanya. Berdasarkan beberapa kemungkinan penyebab tersebut peneliti berusaha mencari penyebab yang muncul di kelas mengenai minat siswa dalam pembelajaran PKn masih rendah karena pengajaran materi kurang menarik, sarana pendukung (alat peraga) untuk pembelajaran masih rendah dan kompetensi guru dalam merencanakan.

Menghadapi kondisi yang sangat mengkhawatirkan, maka perlu adanya upaya perbaikan dalam proses pembelajaran agar dapat meningkatkan keterampilan proses dalam pembelajaran PKn yaitu khususnya pada kemampuan analisis dalam memahami materi PKn Salah satu alternatif yang digunakan yaitu dengan menggunakan model pembelajaran berbasis masalah (Problem Based Learning) dengan media audio visual. Model pembelajaran berbasis masalah (PBL) dengan media audio visual merupakan suatu pendekatan dalam pembelajaran yang membantu siswa untuk menemukan masalah dari suatu peristiwa yang nyata, mengumpulkan informasi melalui strategi yang telah ditentukan sendiri untuk mengambil satu keputusan pemecahan masalahnya yang kemudian akan dipresentasikan dalam bentuk unjuk kerja. Menurut penelitian Jayadiningrat, M. G., \& Ati, E. K. (2018) Problem Based Learning dapat meningkatkan keterampilan memecahkan masalah pada mata pelajaran Kimia

Dengan penerapan model pembelajaran berbasis masalah (PBL) dengan media audio visual diharapkan kemampuan analisis siswa dapat meningkat. Pembelajaran berbasis masalah tidak bisa terlepas dari metode pemecahan masalah, hal ini karena pembelajaran masalah berakar dari metode pemecahan masalah. Metode pemecahan masalah merupakan salah satu cara penyajian bahan pelajaran yang menjadikan masalah sebagai titik tolak pembahasan untuk dianalisis dan disintesis untuk menemukan jawaban.

Pembelajaran berbasis masalah (PBL) menekankan pentingnya pembelajaran melalui pengalaman (belajar dari pengalaman). Pembelajaran di sekolah seharusnya memanfaatkan rasa keingintahuan yang alamiah dengan membawa dunia luar ke dalam ruang kelas, dengan membuatnya tersedia dan dapat diakses untuk keperluan pembelajaran (Jacobsen et al.,2009). Pembelajaran berbasis masalah yang dilakukan secara aktif menyebabkan siswa lebih memahami konsep pengetahuan (Glassersfeld, 2005). PBL adalah salah satu model aliran pembelajaran konstruktivis yang menuntut siswa melakukan pengamatan realitas yang terdapat dalam kehidupan seharihari (Nurhadi,2004). Pembelajaran konstruktivis memberikan kesempatan siswa untuk menemukan konsep pengetahuan. Proses konstruktivis yang dilakukan secara bersama memberikan kesempatan siswa untuk membandingkan ide-ide dari anggota kelompok, mengungkapkan pengetahuannya, dan belajar dari anggota kelompok (Good and Brophy, 1999). Peran guru dalam pembelajaran konstruktivis adalah sebagai pemandu dan fasilitator bagi siswa dalam mendorong siswa untuk menuangkan pembelajaran yang menuntut siswa menemukan konsep pengetahuan secara mandiri. Dalam pembelajaran PBL, siswa mengkonstruksi pengetahuan berdasarkan informasi dan data dikumpulkan oleh mereka dalam lingkungan belajar yang eksploratif. Model PBL merupakan pembelajaran 
kolaboratif, dimana siswa membangun pengetahuan melalui komunikasi timbal balik dan penggunaan bersama alat dan berbagi representasi (Linden et al., 2000) (Prasetyanti, 2016).

Problem Based Learning adalah seperangkat model mengajar yang menggunakan masalah sebagai fokus untuk mengembangkan keterampilan pemecahan masalah, materi, dan pengaturan-diri (Hmelo-Silver, 2004; Se rafino\& Cicchelli, 2005 , Egen dan Kauchak, 2012: 307). PBL merupakan suatu pendekatan pembelajaran yang menggunakan masalah dunia nyata sebagai suatu konteks bagi peserta didik untuk belajar tentang cara berpikir kritis dan keterampilan pemecahan masalah, serta untuk memperoleh pengetahuan dan konsep yang esensial dari materi pelajaran. PBL merupakan pembelajaran berdasarkan teori kognitif yang didalamnya termasuk teori belajar konstruktivisme. Menurut teori konstruktivisme, keterampilan berpikir dan memecahkan masalah dapat dikembangkan jika peserta didik melakukan sendiri, menemukan, dan memindahkan kekomplekan pengetahuan yang ada. Anita Woolfolk (2007:352) mengatakan: The goals of problem based learning are to help students develop flexible knowledge that can be applied in many situations, in contrast to inert knowledge other goals of problem based learning are to enhance intrinsic motivation and skills in problem solving, collaboration, and self directed lifelong learning Menurut Arends (2008:55), langkahlangkah dalam melaksanakan PBL ada 5 fase yaitu (1) mengorientasi siswa pada masalah; (2) mengorganisasi siswa untuk meneliti; (3) membantu investigasi mandiri dan berkelompok; (4) mengembangkan dan menyajikan hasil karya; (5) menganalisis dan mengevaluasi proses pemecahan masalah., permasalahan yang digunakan dalam PBL adalah permasalahan yang dihadapi di dunia nyata. Meskipun kemampuan individual dituntut bagi setiap siswa, tetapi dalam proses belajar dalam PBL siswa belajar dalam kelompok untuk memahami persoalan yang dihadapi. Kemudian siswa belajar secara individu untuk memperoleh informasi tambahan yang berhubungan dengan pemecahan masalah. Peran guru dalam PBL yaitu sebagai fasilitator dalam proses pembelajaran.

Scriven \& Paul (2008) mengungkapkan bahwa dalam berpikir kritis terdapat keterampilan mengaplikasikan, menganalisa, mensintesa, mengevaluasi informasi yang diperoleh dan mengeneralisasi hasil yang diperoleh dari observasi, pengalaman, refleksi, penalaran, atau komunikasi. Berpikir kritis tidak serta merta melekat pada seseorang sejak lahir. Akan tetapi, berpikir kritis merupakan keterampilan yang dapat dikembangkan melalui pengalaman langsung siswa dalam menghadapi permasalahan. Sehingga, jika siswa terbiasa menggunakan keterampilan diatas maka keterampilan berpikir kritis akan dapat berkembang. Tugas guru dalam rangka meningkatkan keterampilan berpikir kritis siswa adalah dengan menyediakan lingkungan belajar yang dapat mendorong siswa menggunakan keterampilan berpikir. Model pembelajaran PBL adalah salah satu model pembelajaran yang dapat menyediakan lingkungan belajar yang mendukung berpikir kritis (Nafiah, 2014).

Menurut Barrow (dalam Huda, 2013, hlm. 271) mendefinisikan Problem Based Learning atau PBL sebagai "Pembelajaran yang diperoleh melalui proses menuju pemahaman atau resolusi suatu masalah". Sementara itu menurut Sujana (2014, hlm. 134) "PBL adalah suatu pembelajaran yang menyuguhkan berbagai situasi bermasalah yang autentik dan berfungsi bagi siswa, sehingga masalah tersebut dapat dijadikan batu loncatan untuk melakukan investigasi dan penelitian". Maka dari itu PBL merupakan sebuah pembelajaran yang menuntut siswa untuk mengkonstruksi pengetahuan mereka sendiri melalui permasalahan. Dari beberapa pendapat di atas dapat disimpulkan bahwa PBL merupakan suatu pembelajaran yang menekankan pada pemberian masalah nyata dalam kehidupan sehari-hari yang harus dipecahkan oleh siswa melalui investigasi mandiri untuk mengasah kemampuan berpikir kreatif dalam pemecahan masalah agar terbentuk solusi dari permasalahan tersebut sebagai pengetahuan dan konsep yang esensial dari pembelajaran. Berikut adalah langkahlangkah PBL menurut Holbrook dan Arends (dalam Sujana, 2014, hlm. 136) yang sudah sedikit dimodifikasi (Abdurrozak, 2016). 


\section{Metode}

Tempat Penelitian Tindakan Kelas (PTK) ini dilaksanakan di SD Negeri 2 Tulikup yang jalan Raya Kembangan, Tulukup, Kabupaten Gianyar. Jadwal pelaksanaan penelitian ini adalah pada semester genap tahun pelajaran 2017/2018 (antara bulan Juli samapai Desember tahun 2017).

Penelitian ini merupakan penelitian tindakan kelas yang akan dilaksanakan dalam dua siklus. Jika pada siklus pertama prestasi belajar PKn siswa belum memenuhi kriteria keberhasilan, maka berdasarkan hasil refleksi akan dilakukan perbaikan pada siklus selanjutnya. Secara operasional prosedur dasar pengembangan tindakan yang akan dilakukan dapat dijabarkan sebagai berikut:

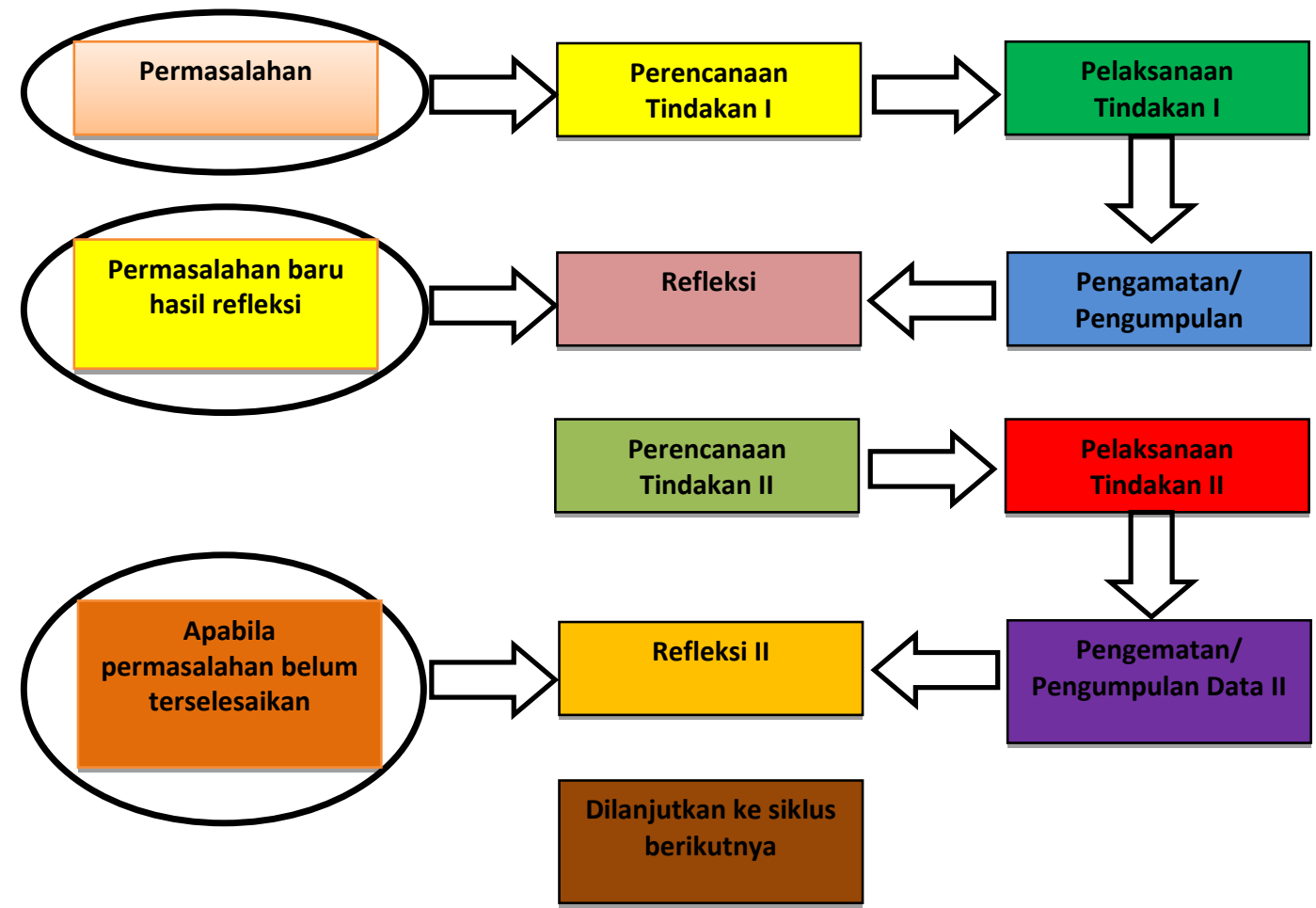

Gambar 1. Penelitian Tindakan Kelas Model Arikunto, Suharsimi, 2007

Prosedur:

1. Perencanaan

Pada tahap ini peneliti membuat RPP, berkonsultasi dengan teman sejawat membuat instrumen. Pada tahap menyusun rancangan diupayakan ada kesepakatan antara guru dan sejawat. Rancangan dilakukan bersama antara peneliti yang akan melakukan tindakan dengan guru lain yang akan mengamati proses jalannya tindakan. Hal tersebut untuk mengurangi unsur subjektivitas pengamat serta mutu kecermatan pengamatan yang dilakukan.

2. Pelaksanaan Tindakan

Tahap pelaksanaan tindakan dilakukan dengan pembelajaran di kelas. Pada tahap ini guru peneliti giat melakukan tindakan menggunakan model pembelajaran Problem Based Learning dengan media audio visual. Rancangan tindakan tersebut sebelumnya telah dilatih untuk dapat diterapkan di dalam kelas sesuai dengan skenarionya. Skenario dari tindakan diupayakan dilaksanakan dengan baik dan wajar.

3. Pengamatan atau observasi

Tahap ini sebenarnya berjalan bersamaan dengan saat pelaksanaan. Pengamatan dilakukan pada waktu tindakan sedang berjalan, jadi, keduanya berlangsung dalam waktu yang sama. Pengamatan juga dilakukan setelah kegiatan selesai yaitu pada saat diadakan kegiatan tes. Guru 
memperhatikan proses yang sedang berlangsung, memperhatikan keaktifan siswa dan guru menilai sikap siswa saat menjawab soal.

Pada tahap ini, guru yang bertindak sebagai peneliti melakukan pengamatan dan mencatat semua hal yang diperlukan dan terjadi selama pelaksanaan tindakan berlangsung. Pengumpulan data ini dilakukan dengan menggunakan tes prestasi belajar yang telah tersusun, termasuk juga pengamatan secara cermat pelaksanaan skenario tindakan dari waktu ke waktu serta dampaknya terhadap proses dan prestasi belajar siswa.

4. Refleksi

Tahapan ini dimaksudkan untuk mengkaji secara menyeluruh tindakan yang telah dilakukan, berdasarkan data yang telah terkumpul, kemudian dilakukan evaluasi guna menyempurnakan tindakan berikutnya.

Refleksi dalam PTK mencakup analisis, sintesis, dan penilaian terhadap hasil pengamatan atas tindakan yang dilakukan. Jika terdapat masalah dari proses refleksi maka dilakukan proses pengkajian ulang melalui siklus berikutnya yang meliputi kegiatan: perencanaan ulang, tindakan ulang, dan pengamatan ulang sehingga permasalahan dapat teratasi Metode yang digunakan untuk menganalisis data hasil penelitian ini adalah metode deskriptif. Untuk data kuantitatif dianalisis dengan mencari mean, median, modus, membuat interval kelas dan melakukan penyajian dalam bentuk tabel dan grafik. Indikator keberhasilan penelitian yang diusulkan dalam penelitian ini pada siklus I dan siklus II mencapai nilai rata-rata 75,00 dengan ketuntasan belajar $85 \%$ atau lebih.

\section{Hasil dan Pembahasan}

Untuk Problem Based Learning (PBL) adalah metode pengajaran yang bercirikan adanya permasalahan nyata sebagai konteks untuk para peserta didik belajar berfikir kritis dan keterampilan memecahkan masalah, dan memperoleh pengetahuan (Duch,1995). Empat penerapan esensial dari Problem Based Learning adalah seperti diurutkan dalam Gallagher et.al (1995) adalah:

1) Orientasi siswa pada masalah

Pada saat mulai pembelajaran, guru menyampaikan tujuan pembelajaran secara jelas, menumbuhkan sikap positif terhadap pelajaran. Guru menyampaikan bahwa perlu adanya elaborasi tentang hal-hal sebagai berikut:

a. Tujuan utama dari pembelajaran adalah tidak untuk mempelajari sejumlah informasi baru, namun lebih kepada bagaimana menyelidiki masalah-masalah penting dan bagaimana menjadikan pembelajar yang mandiri.

b. Permasalahan yang diselidiki tidak memiliki jawaban mutlak "benar". Sebuah penyelesaian yang kompleks memiliki banyak penyelesaian yang terkadang bertentangan.

c. Selama tahap penyelidikan dalam pembelajaran, siswa didorong untuk mengajukan pertanyaan dan mencari informasi dengan bimbingan guru.

d. Pada tahap analisis dan penyelesaian masalah siswa didorong untuk menyampaikan idenya secara terbuka.

2) Mengorganisasikan siswa untuk belajar

Problem Based Learning membutuhkan keterampilan kolaborasi diantara siswa menurut mereka untuk menyelidiki masalah secara bersama. Oleh karena itu mereka juga membutuhkan bantuan untuk merencanakan penyelidikan dan tugas-tugas belajarnya. Mengorganisasikan siswa ke dalam kelompok-kelompok belajar kooperatif juga berlaku untuk mengorganisasikan siswa ke dalam kelompok Problem Based Learning. Intinya di sini adalah guru membantu siswa mendefinisikan dan mengorganisasikan tugas belajar yang berhubungan dengan masalah yang akan dipecahkan.

3) Membantu penyelidikan siswa

Pada tahap ini guru mendorong siswa untuk mengumpulkan data-data atau melaksanakan eksperimen sampai mereka betul-betul memahami dimensi dari masalah tersebut. Tujuannya agar siswa mengumpulkan cukup informasi untuk membangun ide mereka sendiri. Siswa akan membutuhkan untuk diajarkan bagaimana menjadi penyelidik 
yang aktif dan bagaimana menggunakan metode yang sesuai untuk masalah yang sedang dipelajari.

Setelah siswa mengumpulkan cukup data mereka akan mulai menawarkan penjelasan dalam bentuk hipotesis, penjelasan dan pemecahan. Selama tahap ini guru mendorong semua ide dan menerima sepenuhnya ide tersebut.

4) Mengembangkan dan menyajikan hasil karya

Pada tahap ini guru membantu siswa dalam merencanakan dan menyiapkan hasil karya yang akan disajikan. Masing-masing kelompok menyajikan hasil pemecahan masalah yang diperoleh dalam suatu diskusi. Penyajian hasil karya ini dapat berupa laporan, poster maupun media-media yang lain.

5) Menganalisis dan mengevaluasi proses pemecahan masalah

Tahap akhir ini meliputi aktivitas yang dimaksudkan untuk membantu siswa menganalisis dan mengevaluasi proses berpikir mereka sendiri dan disamping itu juga mengevaluasi keterampilan penyelidikan dan keterampilan intelektual yang telah mereka gunakan.

Berdasarkan penelitian yang dilakukan dengan menerapkan model pembelajaran Problem Based Learning mendapatkan hasil yang cukup baik. Hal ini tercermin dari hasil berikut. Data awal yang diperoleh dengan rata-rata 69,68 dengan ketuntasan belajar hanya mencapai 46,87\% menunjukkan bahwa kemampuan anak/siswa dalam mata pelajaran PKn masih sangat rendah mengingat kriteria ketuntasan belajar siswa untuk mata pelajaran ini di SD Negeri 2 Tulikup adalah 75,00. Dengan nilai yang sangat rendah seperti itu maka peneliti mengupayakan untuk dapat meningkatkan prestasi belajar anak/siswa melalui penerapan model pembelajaran Problem Based Learning dengan media audio visual. Akhirnya dengan penerapan penerapan model pembelajaran Problem Based Learning dengan media audio visual yang benar sesuai teori yang ada, peningkatan rata-rata prestasi belajar anak/siswa pada siklus I dapat diupayakan dan mencapai rata-rata 75,31. Namun rata-rata tersebut belum maksimal karena hanya 15 siswa memperoleh nilai di atas KKM sedangkan yang lainnya belum mencapai KKM. Sedangkan prosentase ketuntasan belajar mereka baru mencapai $75,00 \%$. Hal tersebut terjadi akibat penggunaan penerapan model pembelajaran Problem Based Learning dengan media audio visual belum maksimal dapat dilakukan disebabkan penerapan model/metode tersebut baru dicobakan sehingga guru masih belum mampu melaksanakannya sesua alur teori yang benar.

Pada siklus ke II perbaikan prestasi belajar siswa diupayakan lebih maksimal dengan peneliti membuat perencanaan yang lebih baik, menggunakan alur dan teori dari penerapan model pembelajaran Problem Based Learning dengan media audio visual dengan benar dan lebih maksimal. Peneliti giat memotivasi siswa agar giat belajar, memberi arahan-arahan, menuntun mereka untuk mampu menguasai materi pelajaran pada mata pelajaran PKn lebih optimal. Akhirnya dengan semua upaya tersebut peneliti mampu meningkatkan prestasi belajar siswa pada siklus II menjadi rata-rata 81,25 dengan presentase ketuntasan mencapai 96,87\%, hal ini menunjukkan terjadinya peningkatan yang sangat signifikan. Upaya-upaya yang maksimal tersebut menuntun pada suatu keberhasilan bahwa penerapan model pembelajaran Problem Based Learning dengan media audio visual mampu meningkatkan prestasi belajar PKn siswa kelas VI SD Negeri 2 Tulikup pada semester I tahun pelajaran 2017/2018.

Penerapan model pembelajaran Problem Based Learning dengan media audio visual mampu meningkatkan prestasi belajar PKn juga diperkuat oleh penelitian yang dilakukan oleh Rerung (2017) yang berjudul Penerapan Model Pembelajaran Problem Based Learning (PBL) untuk Meningkatkan Hasil Belajar Peserta Didik SMA pada Materi Usaha dan Energi. Pada penelitiannya dinyatakan bahwa hasil belajar kognitif sebesar $64 \%$ pada siklus I dan $84 \%$ pada siklus II. Sedangkan, hasil belajar psikomotor aspek mempersiapkan alat dan bahan meningkat sebesar $4 \%$, aspek merangkai alat dan bahan meningkat sebesar $6 \%$, aspek melakukan percobaan meningkat sebesar $12 \%$, aspek mengamati percobaan sebesar $7 \%$, dan aspek menyampaikan percobaan meningkat sebesar $8 \%$. Hal ini menunjukkan bahwa penerapan model pembelajaran PBL dapat meningkatkan hasil belajar peserta didik.

\section{Simpulan dan Saran}


Berdasarkan Simpulan yang dapat disampaikan berdasarkan semua hasil analisis data yang telah dilakukan adalah penerapan model pembelajaran Problem Based Learning dengan media audio visual dapat meningkakan presasi belajar PKn siswa kelas VI SD Negeri 2 Tulikup semester I tahun pelajaran 2017/2018.

Saran yang disampaikan berdasarkan penelitian yang telah dilakukan adalah sebagai berikut.Siswa disarankan untuk meningkatkan kemampuan berpikir kritisnya, sehingga mampu menjawab segala permasalahan-permasalahan yang ditemui dalam kegiatan pembelajaran.

Guru disarankan untuk mengembangkan pembelajaran inovatif dalam pembelajaran, sehingga siswa menjadi senang dan tidak cepat bosan dalam mengikuti pembelajaran guru.

Peneliti lain disarankan untuk mengembangkan penelitian ini dengan menggunakan berbagai macam variabel lainnya.

\section{Daftar Pustaka}

Abdurrozak, Rizal. 2016. Pengaruh Model Problem Based Learning Terhadap Kemampuan Berpikir Kreatif Siswa . Jurnal Pena Ilmiah: Vol. 1, No, 1 (2016).

Arikunto, Suharsimi. 2007. Manajemen Penelitian. Jakarta: Rineka Cipta.

Duch. 1995. Pembelajaran Berbasis Masalah. Jakarta: Sejarah Indonesia.

Hernawan, Asep Herry, dkk. 2008. Pengembangan Kurikulum dan Pembelajaran. Jakarta : Universitas Terbuka.

Jayadiningrat, M. G., \& Ati, E. K. 2018. Peningkatan Keterampilan Memecahkan Masalah Melalui Model Pembelajaran Problem Based Learning (Pbl) Pada Mata Pelajaran Kimia. Jurnal Pendidikan Kimia Indonesia, 2(1), 1-7.

Nafiah, Yunin Nurun. 2014. Penerapan Model Problem-Based Learning Untuk Meningkatkan Keterampilan Berpikir Kritis Dan Hasil Belajar Siswa . Jurnal Pendidikan Vokasi, Vol 4, Nomor 1, Februari 2014

Prasetyanti, Nanik Murti. 2016. Penerapan Model Pembelajaran Problem Based Learning (Pbl) Untuk Meningkatkan Kemampuan Proses Berpikir Kognitif Siswa Kelas Xi Mipa-1 Sma Negeri 3 Surakarta Tahun Pelajaran 2015/2016 . Jurnal Inkuiri Issn: 2252-7893, Vol 5, No. 2, 2016 (Hal 1-7).

Rerung, Nensy, dkk. 2017. Penerapan Model Pembelajaran Problem Based Learning (PBL) untuk Meningkatkan Hasil Belajar Peserta Didik SMA pada Materi Usaha dan Energi. EJurnal IImiah Pendidikan Fisika AL-Biruni Volume 6 Nomor 1.

Rianto, Milan . 2005. Metode Pembelajaran. Jakarta : Departemen Pendidikan Nasional

Saat, Sulaiman. 2015. Faktor-Faktor Determinan Dalam Pendidikan (Studi Tentang Makna dan Kedudukannya dalam Pendidikan). Jurnal Al-Ta'dib Vol. 8 No. 2, Juli-Desember 